\title{
Preliminary Morphological Study and Food Uptake Experiment for Transmission of Gregarine Infection from Infected Bivalves, Anadara cornea (Reeve, 1844) to the Mud Crab Genus Scylla as an Intermediate Host.
}

Mohd Ihwan Zakariah ( $\nabla$ ihwanz@umt.edu.my)

Universiti Malaysia Terengganu https://orcid.org/0000-0003-3061-0427

Hassan Mohd Daud

Universiti Putra Malaysia Fakulti Perubatan Veterinar

Marina Hassan

Institute of Tropical Aquaculture (AKUATROP)

Reuben Kumar Sunil Sharma

Putra University Malaysia: Universiti Putra Malaysia

Mhd. IKhwanuddin Abdullah

Institute of Tropical Aquaculture and Fisheries (AKUATROP)

Research note

Keywords: Gregarines Apicomplexan, Scylla spp. Aquatic Animal and Aquaculture

Posted Date: October 23rd, 2020

DOl: https://doi.org/10.21203/rs.3.rs-94962/v1

License: (c) (i) This work is licensed under a Creative Commons Attribution 4.0 International License. Read Full License 


\section{Abstract}

Objective: Research about gregarine become important due to the problem reported by this parasite especially in commercial bivalve i.e. Oyster. Diagnose of these parasites are important to secure the aquaculture industry in the future. Due to the advanced technologies nowadays, this research regarding to these parasites are become relevant to be study. The objective of this study is to determine the occurrence of gregarine parasites in wild mud crab and the food uptake transmission of gregarine infection from infected bivalves, Anadara cornea (Reeve, 1844) to the mud crab genus Scylla.

Result: Preliminary study show that high prevalence of infection was reported in the Hairy Cockle (Anadara cornea) from Setiu Lagoon, Malaysia. From the analysis, the infection intensity was high and each phagocyte (Pha) contain maximum of 15 oocyst (Oc). Each oocyst has a single cell wall, longitudinal shape and contained sporozoite ( $\mathrm{Sz}$ ). Parasitophorous Vacuole (Pv) cover by membrane wall. There is no transmission of parasites reported in this experiment.

\section{Introductions}

The apicomplexan gregarines generally are not noted for being highly detrimental to their hosts, the best-known effect being damage done to the epithelial cells to which the young trophozoites are attached in the intestine of the host [36]. This effect, whatever it may be, is directly related to the number of parasites present, since each parasite attacks a single host cell. This could suggest the possibility of a cumulative effect on the host. It also seems quite possible that such an effect may accompany the progressive mechanical obstruction of the blood vessels of the organs involved. It is also conceivable, as suggestion by Sprague and Orr [28] that toxic end products of metabolism might be liberated into the host tissues by the developing sporoblasts.

\section{Methods}

\section{General Methodology}

Most of morphological identification method was referred to expert $[10 ; 15 ; 18 ; 23 ; 32-33 ; 26-27 ; 28-29]$. For the prevalence and mean intensity of the parasites, standard method of analysis is referred to previous research published worldwide [20;24;25]. David, et al., [14] apply method for environmental genetic method in parasitology.

\section{Parasitology Diagnosis}

Parasitology diagnosis were prepared by referring to Tuntiwaranuruk et al. [37]. A piece of tissue (approximately $4 \mathrm{~mm}^{2}$ ) from each sample was removed from the endo and ecto part of body on both sides of the bivalve. The tissue was immediately squashed between glass slides and observed under compound and light microscope using difference type of lens optics (Nikon Eclipse 80i) and captured for micrograph. In this study, sample for gill and digestive tract of the bivalve [38] are specifically chosen as target area of infections according to previous report [3-4; $17 ; 20]$.

\section{Transmission experiment}

Thirty mud crab genus Scylla were used as a sample for three cycle of experiment. Data on mud crab size and weight were for this study. Total fifteen crab were used for controlled and the other fifteen crabs are using as a test sample. Tank that has been used for this study can be referring to Figure 4 . All thirty crabs are following the moulting procedures to make sure the crab is preferably clear from the parasites. The forced-moulting techniques (leg cutting) were applied. The samples were divided into two tanks with complete aeration and sediment to build the real environment for the crab. The infected bivalves were fed into the crab in the experimental tank while the control tank was fed with thrash fish. After a month, the crab was dissected for diagnosis and genetic test were applied to confirm the transmission occurred or not.

\section{DNA Analysis}

\section{Genetic Sample Collection}

Incubator must be set to $56^{\circ} \mathrm{C}$ before running the extraction and all the work bench apparatus i.e. tip box, micropipette must be sterile with $70 \%$ ethanol to disinfect. A piece of gill and digestive tract of ten samples were isolated from the diagnosed hosts, washed three times in filtered distilled water or in 150 mM physiological $\mathrm{NaCl}$ solution and deposited into a 1.5-ml micro centrifuge tube for extraction using the Qaigen ${ }^{\text {TM }}$ Complete analysis DNA Kit and RNA Purification Kit (Qaigen, US) [26-28]. Result were sent for sequencing and analysed using blasting software MEGA X.

\section{Results}

In the preliminary study, the gregarine has been found infected the gill and intestine tissue of Anadara cornea. The illustrated of the parasites are showed in Fig. 1. From the analysis, the infection intensity was high and each phagocyte (Pha) contain maximum of 15 oocyst (Oc). Each oocyst has a single cell wall, longitudinal shape and contained sporozoite ( $\mathrm{Sz}$ ). Parasitophorous Vacuole (Pv) cover by membrane wall. Histopathology study (Fig. 2) is showing Phagocyte (Pha) in digestive tract and oocysts (Oc) in parasitophorous vacuole (PV); sprozoites (Sz) are clearly visible (Magnification: 400X). Oocysts are commonly found in the parasitized phagocytes. Further analysis will be correlated with the tissue changes by using lesion scoring obtained from previous 
study. Previous study of oocyst also reported by Azevedo and Matos [4] and Clopton [11]. For Scylla spp. Preliminary study, thirty mud crab genus Scylla were collected from Setiu Wetland, Terengganu and observed for preliminary study and one of the crab's sample show positive findings. Average of carapace length $(7.4 \pm 0.7 \mathrm{~cm})$, carapace width $(5.3 \pm 0.4 \mathrm{~cm})$ and body weight $(71.1 \pm 13.5 \mathrm{gram})$ of mud crab genus Scylla recorded for this study. But when the transmission study has been applied, no positive results are showed. The preliminary finding of syzygy-like of gregarine parasites (Fig. 3) was assumedly accidentally found cases. Table 1 show the summarized results of transmission experiment between two species of host. For the genetic study, there is no positive result that showing the transmission of the parasites between intermediate and definitive host. Table 1 show the test replication with the diagnosis of every mud crab. Sample for DNA study are randomly collected from different part of mud crab possibilities infected organ. Sample that has been collected is standardized taken from gut, intestine, gill and hepatopancreas which is suggested from previous study. Overall result did not show any positive infections. Further study is needed to double confirm whether the transmission is really happened. The sample of crab and bivalves are prepared with controlled the cleanliness of the samples as much as it can through the standard quarantine process. The crabs for experiment were through the moulting process and the next step is fed with pellet which is assumedly free from gregarine parasites. The crabs also were bath in the $10 \%$ formalin for 24 hours to make sure that another suspected parasite is eliminated. The infected bivalve is selected by the diagnosis of the sample. All the infected of bivalves were collected and fed to the crab within 2-3 weeks. The number of bivalves which is fed to the crab is not specified because this experiment is only wanted to explore the transmission is happen or not. Details for the transmission should be applied if future experiments of lifecycle of this parasite are done.

Table 1

Parasitological diagnosis and DNA analysis for the testing samples during the experiment of four-month study periods ( 3 set of experiment were done which involved 30 crabs).

\begin{tabular}{|c|c|c|c|c|c|}
\hline \multirow[t]{2}{*}{ Duration } & \multirow[t]{2}{*}{ Crab Sample } & \multicolumn{3}{|c|}{ Parasitology Diagnosis } & \multirow[t]{2}{*}{ DNA Analysis } \\
\hline & & Experiment 1 & Experiment 2 & Experiment 3 & \\
\hline \multirow[t]{10}{*}{5 Aug - 5 Nov 2018} & Control 1 & -ve & -ve & -ve & -ve \\
\hline & Control 2 & -ve & -ve & -ve & -ve \\
\hline & Control 3 & -ve & -ve & -ve & -ve \\
\hline & Control 4 & -ve & -ve & -ve & -ve \\
\hline & Control 5 & -ve & -ve & -ve & -ve \\
\hline & Testing 1 & -ve & -ve & -ve & -ve \\
\hline & Testing 2 & -ve & -ve & -ve & -ve \\
\hline & Testing 3 & -ve & -ve & -ve & -ve \\
\hline & Testing 4 & -ve & -ve & -ve & -ve \\
\hline & Testing 5 & -ve & -ve & -ve & -ve \\
\hline
\end{tabular}

\section{Discussions}

Effect of the gregarine infections in aquatic organisms nowadays are reported due to the importance of this parasite [5-7]. Most of the infections reported from the commercial species culture are related to the requirement of World Organization for Animal Health (OIE) [30; 35]. This information is important because of these parasites are that can give serious impact to the sustainability of aquaculture in the future. Movement of the parasites is very important to fulfil the complete lifecycle [34]. Some study explained this parasite able to shift and can adjust the direction along the surface through gliding movement [13; 40] without use of any organs such as cilia, flagella, etc. Previous research stated that the motility is happen using complex combination including myosin with the involvedness of actin cytoskeleton to perform the gliding motion [40]. Some study stated that the epicytes of all the gregarines is differentiated into a system of regular longitudinal folds [9]. Some gregarine species folds heave supports the parasites to glide along [39]. Most of the study shows that abiotic and biotic factors give an effect to the changes of terrestrial and aquatic habit in natural system of the parasites [12;16]. Normally host can interact precisely and implicit the situation of transmission process. This can also detrimentally to regulate the natural parasite transmission process [9;15;41]. Natural habitat should be maintained the ecosystem because if the structure, biodiversity, host-demographics, evolution are disturbed, the sustainability of the ecosystem will be destroyed [8-9]. Significant climate change commonly affects the water quality such as temperature, salinity [16], dissolved oxygen and pH. This factor is very important to relate the distribution of this parasites among the local host in the specific area of sampling study [21;22]. Some information relates to this mechanism of interaction between environmental stressors [2] and the subsequent effect on parasites transmission are precisely complicated [9; 19]. The factor that increasing the prevalent parasites intensity [31], growth, reproduction and infection are thoroughly define by the fluctuation of temperature and yet can contribute to the high mortality if it is not controlled properly.

\section{Conclusion}

Nowadays, the seafood consumption demand by human is increase throughout year. The common cultured species did not support the demand and now a lot of new species are introduced for species culture including crustacean species. This study purposely shows the morphology of the gregarine and some information added to explore the further study of this parasites. Histopathology of gregarine infection also show the infection of the parasites. Previous review of this parasites has been potential to explore this scope of study to the next level of research. Transmission experiments show negative result. Further tests need to be done to confirm the transmission. 


\section{Limitations}

This work was carried out as a preliminary study at a single site. In this study, sample that were used declare a seafood, we investigated the experiment and get the sample from the live market by local fisherman. Parasite that were collected for morphology study are too tiny and live specimen were used for identification. No latest journal is available.

\section{Abbreviations}

DNA: deoxyribonucleic acid; PCR: Polymerase chain reaction; Pha: phagocyte; Oc: oocyst; Sz: sporozoite; Pv: Parasitophorous Vacuole.

\section{Declarations}

\section{Acknowledgement}

A wish of thank to Institute of Tropical Aquaculture and Fisheries (AKUATROP), Universiti Malaysia Terengganu (UMT) and Faculty of Veterinary Medicine (UPM) for giving me the opportunity to continue my study. Staff of UPM and UMT who are willing support especially to Mrs. Farizan Abdullah, Mrs. Wahidah Wahab, Mr. Ahmad Shuhaimi Draman, Mr. Ahmad Najmi Ishak, Dr. Mohd Fuad, Mrs. Latifah and people that helping me directly or indirectly.

\section{Declaration}

This study did not involve the ethics approval and consent to participate. It also not gives permission for publication. There are no competing interests and funding supported for this study

\section{Authors' contributions}

Mohd Ihwan Zakariah is an expert in aquatic parasitology and designed the study. Hassan Mohd Daud, Marina Hassan and Reubern Sunil Kumar Sharma is aquatic veterinary expert for morphology and genetic study. Mhd. Ikhwanuddin Abdullah Expert in crustacean species of culture. All authors read and approved the final manuscript.

\section{Funding}

This study did not receive any specific grants from funding agencies in the public, commercial, or not-for-profit sectors.

\section{Availability of data and materials}

All data generated or analysed during this study are included in this published article. The original datasets are available upon request to the corresponding author.

\section{Ethics approval and consent to participate}

Both species used in the present study, mud crab, Scylla spp. and Blood cockle, Anadara spp. are common commercial fishery caught species and require no approval to utilise them. Both species also are been handled accordingly following Universiti Malaysia Terengganu Animal Ethical Committee guilds lines. The examined of Scylla spp. and bivalves were part of this study. The sample of crab and bivalves are prepared with controlled the cleanliness of the samples as much as it can through the standard quarantine process.

\section{Consent for publication}

Not applicable.

\section{Competing interests}

The authors declared no conflicts of interest

\section{Author Details}

${ }^{1}$ Faculty of Veterinary Medicine, Universiti Putra Malaysia (UPM), 43400 UPM Serdang, Selangor, Malaysia. ${ }^{2}$ Institute of Tropical Aquaculture and Fisheries (AKUATROP), Universiti Malaysia Terengganu (UMT), 21030 Kuala Nerus, Terengganu, Malaysia.

\section{References}


1. Anderson R.S. (2001) Reactive Oxygen Species and Antimicrobial Defences of Invertebrates: A Bivalve Model. In: Beck G., Sugumaran M., Cooper E.L. (eds) Phylogenetic Perspectives on the Vertebrate Immune System. Advances in Experimental Medicine and Biology, vol 484. Springer, Boston, MA. https://doi.org/10.1007/978-1-4615-1291-2_12 https://link.springer.com/chapter/10.1007/978-1-4615-1291-2_12

2. Azevedo C. and Cachola R., (1992). Fine structure of the Apicomplexa oocyst of Nematopsis of the two marine bivalve molluscs. Disease aquatic Organism. 14, 69-73. DOI: 10.3354/dao014069

3. Azevedo, C. and Matos, E., (1999). Description of Nematopsis mytella sp. (Apicomplexa), parasite of the mussel Mytella guyanensis (Mytelidae) from the Amazon estuary and description of its oocysts. European Journal of Protistology. 35,427-433. https://doi.org/10.1016/S0932-4739(999) 80052-2

4. Ball, G. H. (1938). The life history of Carcinoecetes hesperus gen., n. sp., a gregarine parasite of the striped shore crab, Pachygrapsus crassipes, with observations on related forms. Arch. Protistenk. 90, 301-19. Publishing.

5. Ball, G. H. (1933). Observations on Life History of a Gregarine of the Striped Shore Crab, Pachygrapsus crassipes. Proceedings of the Society for Experimental Biology and Medicine, 31(1), 91-93. https://doi.org/10.3181/00379727-31-7009P

6. Ball, G. H. (1959). Some Gregarines from Crustaceans taken near Bombay, India. J. Protozool 6 (1), 8-13. https://doi.org/10.1111/j.1550-

7408.1959.tb03919.x (https://onlinelibrary.wiley.com/doi/epdf/10.1111/j.1550-7408.1959.tb03919.x)

7. Ball, G. H. (1963). Cephaloidophora carpilodei sp. and C. pinguis n. sp., Gregarines Xanthid Crab in Hawaii. J. Protozool (3), 321-327. D0I: 10.1111/j.15507408.1963.tb01683.x (https://sci-hub.st/https://doi.org/10.1111/j.1550-7408.1963.tb01683.x)

8. Bush, A. O., K. D. Lafferty, J. M. Lotz and A. W. Shostak (1997). Parasitology meets ecology on its own terms: Margolis et al. revisited. J. Parasitol., 83:57583.DOI: 2307/3284227 https://www.jstor.org/stable/3284227?seq=1\#metadata_info_tab_contents

9. Cable Joanne, lain Barber, Brian Boag, Amy R. Ellison, Eric R. Morgan, Kris Murray, Emily L. Pascoe, Steven M. Sait, Anthony J. Wilson, and Mark Booth (2017). Global change, parasite transmission and disease control: lessons from ecology. Philos Trans R Soc Lond B Biol Sci. 2017 May 5; 372(1719): 20160088. doi: 1098/rstb.2016.0088 https://royalsocietypublishing.org/doi/10.1098/rstb.2016.0088

10. Canestri-Trotti G, Baccarani EM, Paesanti F, Turolla E (2000). Monitoring of infections by protozoa of the genera Nematopsis, Perkinsus, and Porospora in the smooth Venus clam Callista chione from the North-Western Adriatic Sea (Italy). Dis Aquat Org 42:157-161. doi: 10.3354/dao042157.

11. Clopton, R. E. (2000). Order Eugregarinorida Léger, The illustrated guide to the Protozoa 2nd Edition. Allen Press Inc., Lawrence. 1900. Pp. 205-298 in J. J. Lee, G. F. Leedale, and P. Bradbury, eds. (http://science.peru.edu/gregarina/PDF/Clopton_2002_IIIGuide\%20Gregarines.pdf )

12. Couch, J.A (1978). Diseases, parasites and toxic responses of commercial penaeid shrimps of the Gulf of Mexico and south Atlantic coasts of North America. Fish Bull (Wash DC) 76:1-44. (https://spo.nmfs.noaa.gov/sites/default/files/pdf-content/1978/761/couch.pdf)

13. David Bass, Grant D. Stentiford, D.T.J. Littlewood, Hanna Hartikainen, (2015). Diverse Applications of Environmental DNA Methods in Parasitology, Trends in Parasitology, Volume 31, Issue 10, Pages 499-513, ISSN 1471-4922, https://doi.org/10.1016/j.pt.2015.06.013.

(http://www.sciencedirect.com/science/article/pii/S1471492215001506)

14. Erazo-Pagador, G. (2010). A parasitological survey of slipper-cupped oyster (Crassostrea iredalei Faustino, 1932) in the Philippines. Journal of Shellfish Research, 29, 177-179. DOI: 2983/035.029.0111

15. Galloway, T.S., Depledge, M.H. Immunotoxicity in Invertebrates: Measurement and Ecotoxicological Relevance. Ecotoxicology 10, 5-23 (2001). https://doi.org/10.1023/A:1008939520263

16. Grant D. Stentiford, (2012). Diseases in aquatic crustaceans: Problems and solutions for global food security. Journal of Invertebrate Pathology, Volume 110, Issue 2, Page 139. ISSN0022-2011,https://doi.org/10.1016/j.jip.2012.04.014.

(http://www.sciencedirect.com/science/article/pii/S0022201112001206)

17. Gauthier, J. D., T. M. Soniat and J. S. Rogers (1990) A parasitological survey of oysters along salinity gradients in coastal Louisiana. J. World Aquaculture Soc., 21:105-15. DOI: 1111/j.1749-7345.1990.tb00530.x

18. Golemansky, V., (2015). Checklist of Gregarines (Apicomplexa: Eugregarinorida and Neogregarinorida) from Bulgaria. Acta zool. bulg., 67 (2), 2015 : 149157. (http://www.acta-zoologica-bulgarica.eu/downloads/acta-zoologica-bulgarica/2015/67-2-149-157.pdf)

19. Haldar D.P. and Sarkar, N.K., (1980). Studies in Three New Species of Cephaline Gregarines of the Genus Gregarina Dufour, 1828 from Indian Gryllids. December 1980. Archiv fü Protistenkunde 123(1):61-71.https://doi.org/10.1016/S0003-9365(80)80038-8 (http://www.sciencedirect.com/science/article/pii/S0003936580800388)

20. Ihwan, M.Z., Wahidah, W., Marina, H., Shaharom-Harisson, F. Rabi-Atun, A.A. and Suhairi, M., (2016). A Case Study of Fish Distress: Prevalence and Mean Intensity of Parasites. Academy of Agriculture Journal 1: 3 May (2016) 56-60. DOI: 15520/aaj.v1i3.13 (https://www.researchgate.net/publication/309548550_A_CASE_STUDY_OF_FISH_DISTRESS_PREVALENCE_AND_MEAN_INTENSITY_OF_PARASITES)

21. Mohd Ihwan Zakariah, Hassan Mohd Daud, Reuben Sunil Kumar Sharma, Mhd. Ikhwanuddin and Marina Hassan (2019). Distribution patterns of gregarine parasitism of wild marine bivalve, Anadara cornea (reeve, 1844) concerning seasonality and water quality. IOP Conference Series Earth and Environmental Science 370:012063. DOI: 10.1088/1755-1315/370/1/012063. (https://iopscience.iop.org/article/10.1088/1755-1315/370/1/012063/pdf )

22. Kamaruzzaman B.Y., Husain M.L., Shazili N.A.M., Sulong, I. and Rashid, K.A. (2002). Study on the Distribution of Some Heavy Metals and Pollution Status of a Tropical Microtidal River: The Chukai-Kemaman River, Terengganu, Malaysia, Dimensions of Pollution 1: 115 130.http://www.ukm.my/jsm/english_journals/vol32_2003/vol32_03page25-35.html 
23. Kamm, M. W., (1922). A List of the New Gregarines Described from 1911 to 1920. Transactions of the American Microscopical Society. Vol. 41 , No. 3 (Jul. 1922), pp. 122-152. DOI: $10.2307 / 3221671$

24. Kua, B. C., and Taha, M.S (2004). A Preliminary Observation of Parasitic Infestation on Blood Cockles (Anadara granosa) and Tropical Oyster (Crassostrea iredalei) in Northern Peninsular Malaysia. Malaysian Fisheries Journal, 3, 125-129.

(https://www.dof.gov.my/fri/resources/MFJ/2004Vol2/2004Vol2_7.jpg )

25. Landau, H. and Galtsoff P.S. (1951). Distribution of Nematopsis infection on the oyster grounds of the Chesapeake Bay and in other waters of the Atlantic and Gulf States. Tex. J. Sci., 3 pp. 115-130

(https://www.researchgate.net/publication/228353500_Distribution_of_parasites_and_pathologies_in_sentinel_bivalves_NOAA_status_and_Trends_Muss

26. Leander, B. S., Clopton, R. E. \& Keeling, P. J., (2003). Phylogeny of gregarines (Apicomplexa) as inferred from small-subunit rDNA and beta-tubulin. International Journal of Systematic and Evolutionary Microbiology, 53, 345-354. doi: 10.1099/ijs.0.02284-0.

27. Leander, B. S., Lloyd, S. A. J., Marshall, W. \& Landers, S. C., (2006). Phylogeny of marine gregarines (Apicomplexa) - Pterospora, Lithocystis and Lankesteria - and the origin (s) of coelomic parasitism. Protist, 157, 45-60. DOI: 1016/j.protis.2005.10.002

28. Leander, B. S., (2007). Molecular phylogeny and ultrastructure of Selenidium serpulae (Apicomplexa, Archigregarinia) from the calcareous tubeworm Serpula vermicularis (Annelida, Polychaeta, Sabellida). Zoologica Scripta, 36, 213-227. https://doi.org/10.1111/j.1463-6409.2007.00272.x

29. Leander, B. S., (2008). Marine gregarines- evolutionary prelude to the apicomplexan radiation? Trends in Parasitology, 24, 60-67. DOI: 1016/j.pt.2007.11.005

30. Liong, P. C., Hanafi, H. B., Merican, Z. O., \& Nagaraj, G. (1988). Aquaculture development in Malaysia (J. V. Juario \& L. V. Benitez (eds.)) [Conference paper] Aquaculture Department, Southeast Asian Fisheries Development Center. (http://hdl.handle.net/10862/140)

31. Meyers, T.R., (1981). Endemic diseases of cultured shellfish of Long Island, New York: adult and juvenile American oysters (Crassostrea virginica) and hard clams (Mercenaria mercenaria). Aquaculture, 22: 305-330. https://doi.org/10.1016/0044-8486(81)90158-7

32. Votýpka J., Modrý D., Oborník M., Šlapeta J., Lukeš J. (2016) Apicomplexa. In: Archibald J. et al. (eds) Handbook of the Protists. Springer, Cham. https://doi.org/10.1007/978-3-319-32669-6_20-1

33. Prasadan, P.K. and Janardanan, P.K. (2001). Three new species of Gregarines (Apicomplexa: Sporozoea: Porosporidae) in the Estuarine Crabs from Kerala, India. Acta Protozool. 2001; 40:303-309. http://www1.nencki.gov.pl/pdf/ap/ap581.pdf (https://www.semanticscholar.org/paper/Three-NewSpecies-of-Gregarines-(Apicomplexa\%3A-in-Prasadan-Janardanan/87176b4c333b5c6d0c1dcaa59248cdc69527334a)

34. Prytherch, H. F., (1940). The life cycle and morphology of Nematopsis ostrearum, sp. Nov. a gregarine parasite of the mud crab and oyster. Journal of Morphology. Volume66, Issue1. Pages 39-65. https://doi.org/10.1002/jmor.1050660106

35. Sayuthi, S. (1993). Fish diseases in Malaysia: Status and problems. In C. T. Villegas, M. T. Castaños, \& R. B. Lacierda (Eds.), Proceedings of the Aquaculture Workshop for SEAFDEC/AQD Training Alumni, 8-11 September 1992, lloilo, Philippines (pp. 57-61). Tigbauan, Iloilo, Philippines: Aquaculture Department, Southeast Asian Fisheries Development Center. http://hdl.handle.net/10862/637 https://repository.seafdec.org.ph/bitstream/handle/10862/637/pawsata_p057-061.pdf?sequence=1\&isAllowed=y

36. Sprague, V and Orr, P. E. J., (1955). Nematopsis ostrearum and prytherchi (Eugregarinina: Porosporidae) with Special Reference to the Host-Parasite Relations. The Journal of Parasitology, Vol. 41, No. 1, pp. 89-104. DOI: 10.2307/3274005

37. Tuntiwaranuruk, C., Chalermwat, K., Upatham, E.S., Kruatrachue, M. C. (2004). Investigation of Nematopsis Oocysts in 7 species of bivalves from Chonburi province, Gulf of Thailand. Diseases of Aquatic Organisms, 58, 47-53. DOI: 10.3354/dao058047

38. Uddin, M. Jasim, Zulfigar,Y., Munawar, K., \& Shau-Hwai, A.T. (2010). Parasites of blood cockle (Anadara granosa Linnaeus, 1758) from the Straits of Malacca. Journal of Shellfish Research, 30(3), 875-880. https://doi.org/10.2983/035.030.0328

39. Vavra, J. and Small, E. B. 1969. Scanning Electron Microscopy of Gregarines (Protozoa, Sporozoa) and Its Contribution to the Theory of Gregarine Movement. The Journal of protozoology 16(4):745-57. https://doi.org/10.1111/j.1550-7408.1969.tb02338.x

40. Walker M. H., C. Mackenzie, S. P. Bainbridge and C. Orme., 2007. A Study of the Structure and Gliding Movement of Gregarina garnhami, The Journal of Protozoology, 26, 4, (566-

574). https://www.researchgate.net/publication/230040038_A_Study_of_the_Structure_and_Gliding_Movement_of_Gregarina_garnhami

41. Wei, L. S. and Wee, W. (2014). Diseases in aquaculture. Research Journal of Animal and Veterinary Sciences. 7(1): 16. http://www.aensiweb.net/AENSIWEB/rjavs/rjavs/2014/1-6.pdf

\section{Figures}




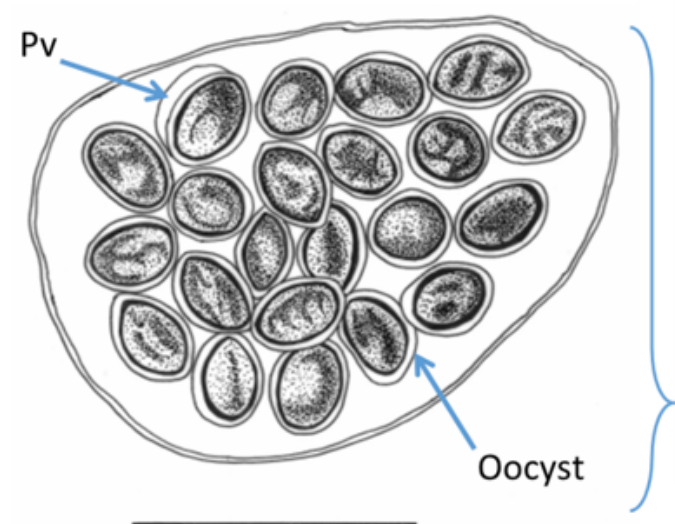

$50 \mu \mathrm{m}$

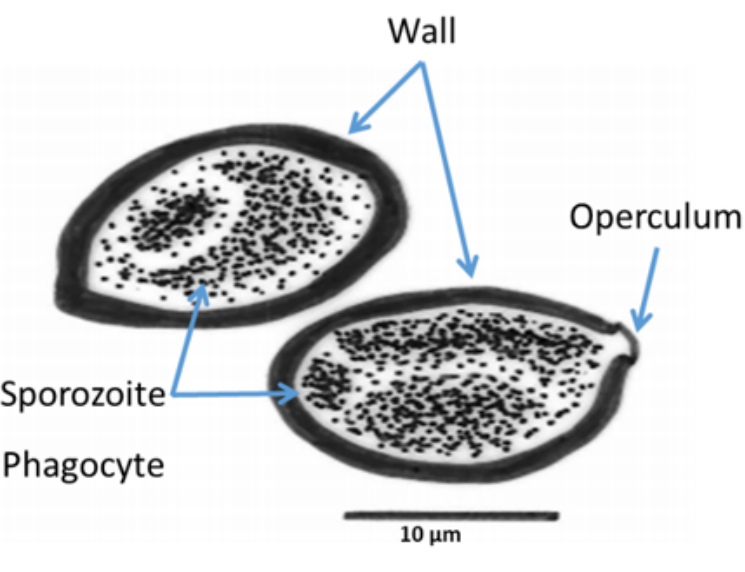

Figure 1

Systematic drawing of the parasites found in wild marine bivalves from Setiu Lagoon, Terengganu, Malaysia.
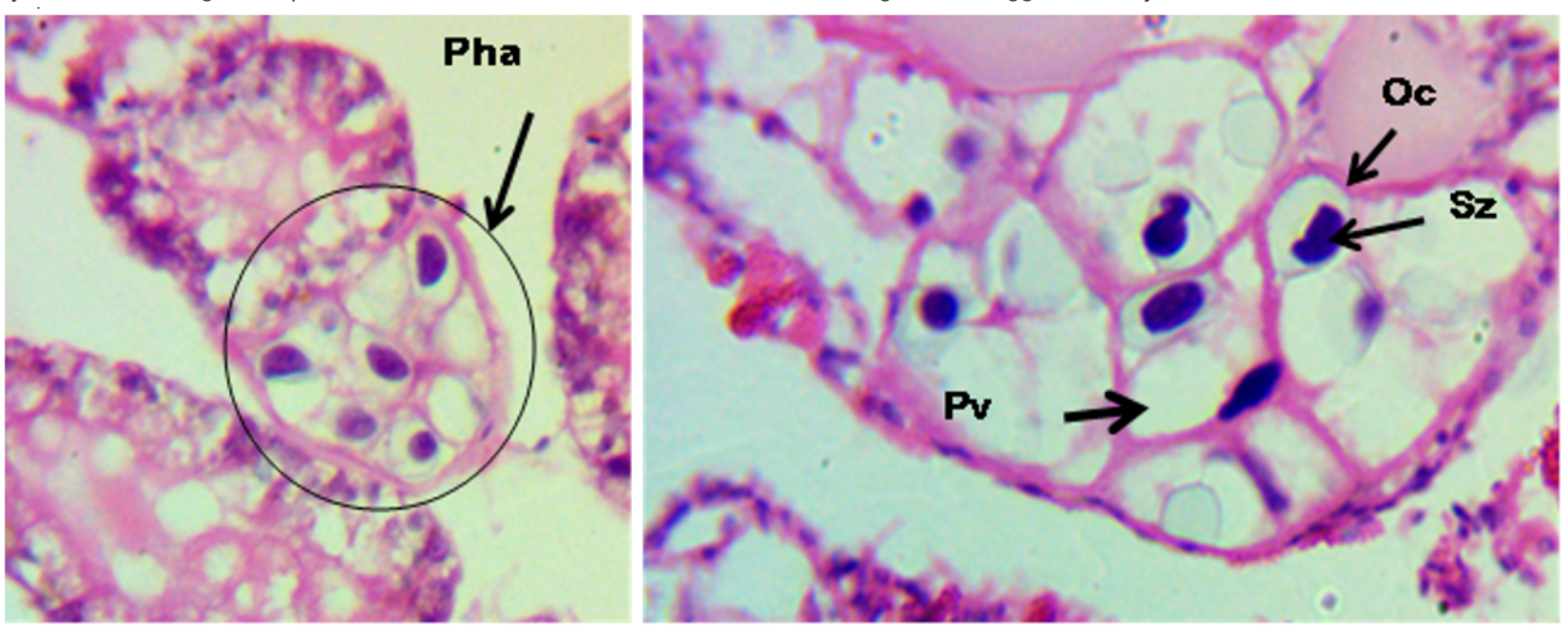

Figure 2

Histological section showing gregarine infecting bivalves obtained from Setiu Lagoon [H\&E stain]

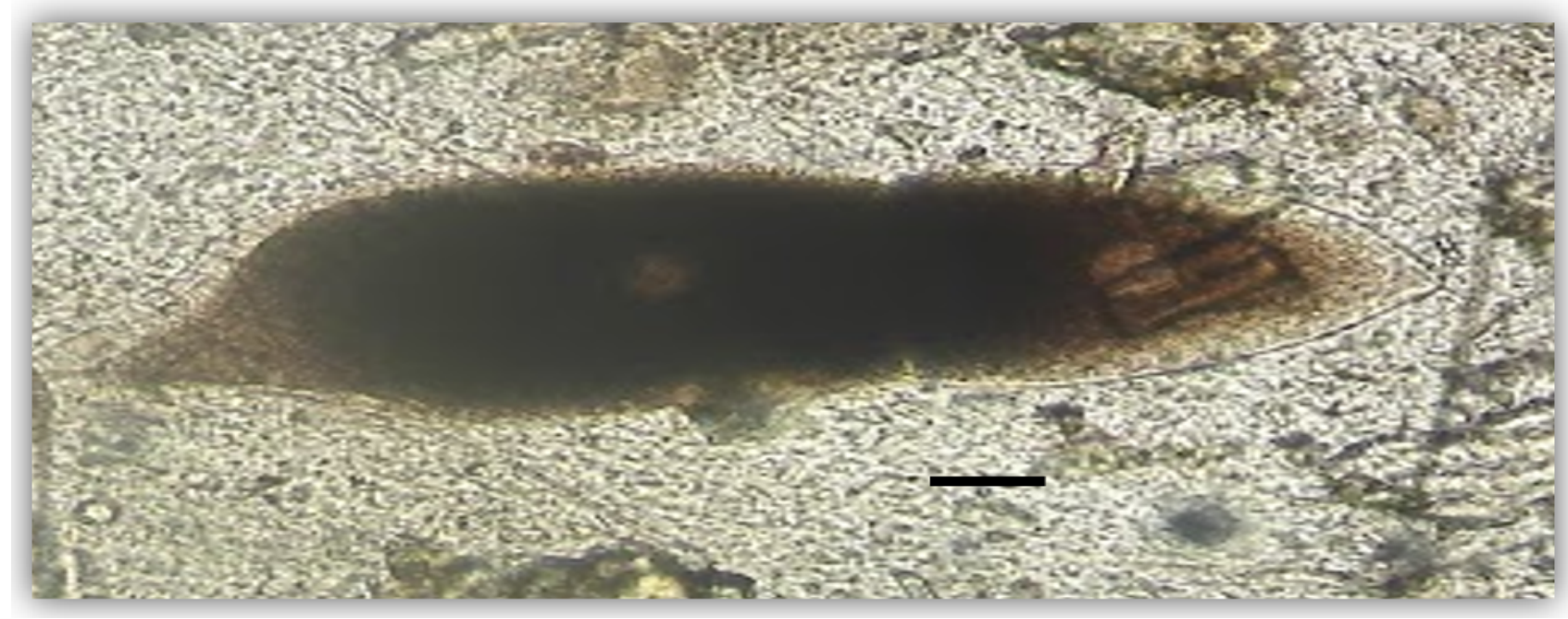

Figure 3

Syzygy-like of sporont in midgut of mud crab genus Scylla. (Bar $=0.5 \mathrm{~mm})$ 


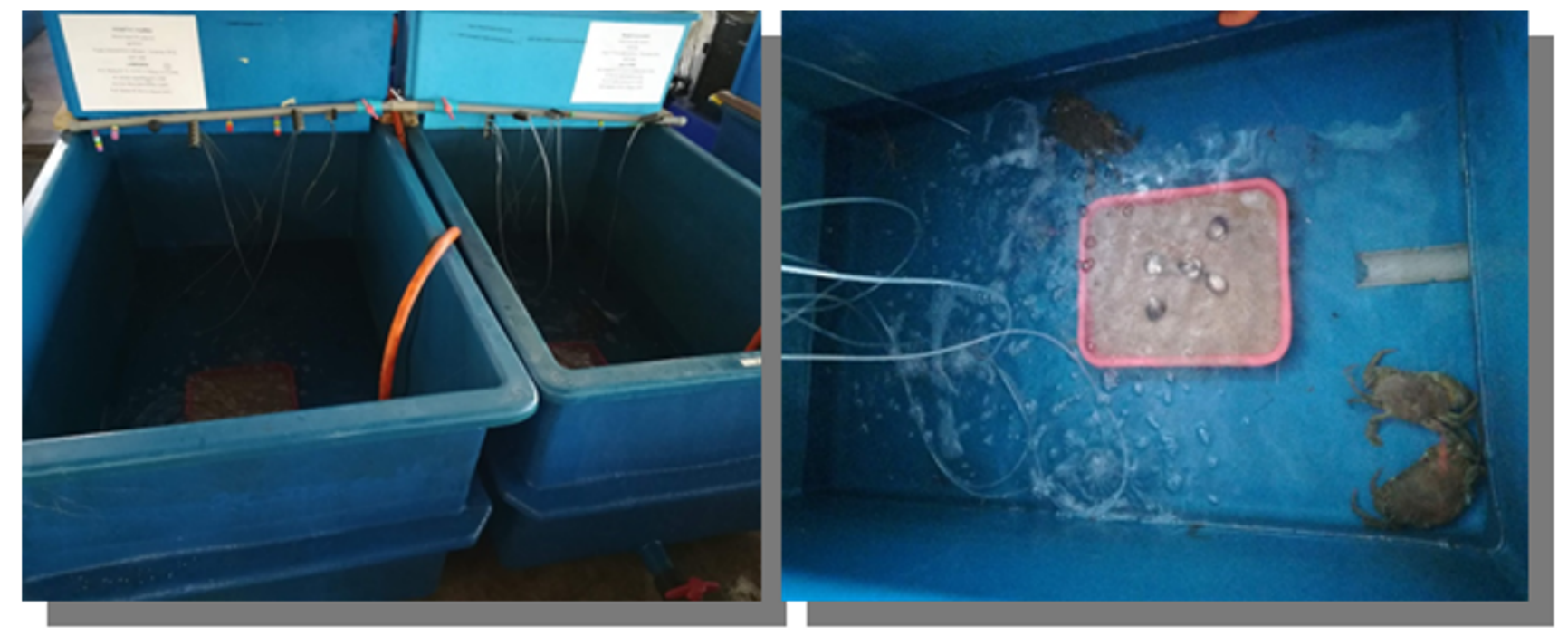

Figure 4

Gregarine parasite transmission experiment. Whole experiment takes about 2 months starting from the moulting process to in-vitro test. 